TITLE:

\title{
Evaluation of Weighted Diffusion Subtraction for Detection of Clinically Significant Prostate Cancer( Digest_要約 )
}

$\operatorname{AUTHOR}(\mathrm{S})$ :

Sato, Toshiyuki

\section{CITATION:}

Sato, Toshiyuki. Evaluation of Weighted Diffusion Subtraction for Detection of Clinically Significant Prostate Cancer. 京都大学, 2021, 博士(医学)

ISSUE DATE:

2021-11-24

URL:

https://doi.org/10.14989/doctor.k23567

RIGHT:

学位規則第9条第2項により要約公開 


\section{論文要約}

\section{【背景】}

MRI (magnetic resonance imaging)撮像法の1つである拡散強調像 (diffusion w eighted imaging:DWI) 及び異なるb值のDWIから得られるapparent diffusion coeffi cient（ADC） map は前立腺癌の検出に重要な画像であり、臨床的に意義のある前立 腺癌 (clinically significant prostate cancer:csPCa)の診断に広く用いられてい るProstate Imaging-Reporting and Data System（PI-RADS）v2.1でも中心的な役割 を果たしている【1】。一方で、PI-RADS v2.1ではADC mapで病変部が「著明な低信 号か否か」を判断することが重要であり、この主観的な評価が診断能のばらつきや 読影者間のスコアの不一致の大きな原因の一つと考えられている【2】。Weighted D iffusion Subtractoin(WDS) は、異なるb值で得たDWIの加重減算により、新たな画像 を作成する手法で、設定した閾值以下のADC值を示す領域が低信号域として明瞭に描 出される【3】。本研究の目的は、WDS画像を用いたスコア (DWI/WDSスコア) とADC ma pを用いた通常のPI-RADS DWIスコア (DWI/ADCスコア)のcsPCaの診断能、読影者間の 一致度を比較し、csPCaの診断におけるWDSの有用性を検討することである。

\section{【方法】}

2015年10月から2019年10月に前立腺全摘術を施行された前立腺癌患者のうち、術 前に治療介入がなく、京都大学医学部附属病院で術前MRIが施行された86症例 (121病 変)を対象とした。撮像には3テスラ装置を用いた。WDS画像はb=0，1500のDWIから 作成した。DWI/WDSスコア、DWI/ADCスコアの診断能と読影者間一致度を4名の放射線 科医により視覚的に評価した。csPCaの検出能はJAFROC解析で評価し、Figure of Me rit（FOM）を算出した。また、4点以上を陽性とした場合の感度、陽性的中率を評価し た。読影者間一致度はkappa statisticsを用いて評価した。定量評価として、WDS画 像とADC mapでの腫瘍・正常前立腺組織間のコントラストを算出した。前立腺全体(o veral1)、辺縁域(peripheral zone:PZ)、移行域(transitional zone:TZ)のそれぞれ で視覚的及び定量的に評価した。

\section{【結果】}

FOM、感度はovera11、PZ、TZのいずれにおいてもDWI/WDSスコアで有意に高值であ った (FOM: overa11, DWI/ADCスコア vs. DWI/WDSスコア，0.715 vs. $0.783 ; \mathrm{PZ,} 0$. 756 vs. 0.815 ; TZ，0.653 vs. 0.738. 感度： 0.512 vs. $0.607 ； 0.485$ vs. 0.573 ; 0.636 vs. 0.761)。陽性的中率もいずれにおいてもDWI/WDSスコアで高值であり、ov era11では有意差をもって高值であった (0.727 vs. 0.777)。読影者間一致度につい ては、overa11、PZでDWI/WDSスコアの $\kappa$ 值が有意に高值であった (overall，0.614 v s. 0.792 ; PZ，0.609 vs. 0.797)。腫瘍・正常前立腺組織間のコントラストについ ては、overa11、PZ、TZのいずれもADC mapと比較してWDS画像で有意に高值を示した 
(overa11, WDS画像 vs. ADC map, 0.46 vs. 1.26; PZ, 0.47 vs. 1.19; TZ, 0.41 v s. 1.61)。

\section{【考察】}

WDS画像ではADC值が閾值以下の領域が明瞭に低信号化し、ADC map と比較して良好 な腫瘍・正常前立腺組織間のコントラストが得られ、ADC mapを用いたPI-RADS v2. 1 のDWIスコアと比較して良好な診断能、読影者間一致度が得られた。

DWIから得られるADC值の前立腺癌の診断への有用性が報告されているが【4】、PI -RADS v2.1のスコアリングは視覚的な評価であり、ADC值は採用されていない。WDS 画像は解剖構造の描出を保持しつつ、ADC值が閾值以下の領域が明瞭に低信号化する ため、画像コントラストにADC值の情報を含んでいる。そのため、この領域を「著明 な低信号」として判断することにより、スコアリングの主観性、曖昧さが軽減し、 良好な診断能、読影者間一致度が得られたと考えられる。

\section{【結論】}

WDS画像ではADC mapより高い腫瘍・正常前立腺組織間のコントラストが得られ、A DC mapを用いたPI-RADS v2.1のDWIスコアと比較して良好な診断能、読影者間一致度 が得られた。WDSはcsPCaの診断に有用と考えられる。

1. Turkbey B, Rosenkrantz AB, Haider MA, et al. Prostate imaging reporti ng and data system version 2. 1: 2019 update of prostate imaging repor ting and data system version 2. Eur Urol 2019;76(3):340-351.

2. Bhayana R, 0' Shea A, Anderson MA, et al. PI-RADS versions 2 and 2. 1: Interobserver agreement and diagnostic performance in peripheral and transition zone lesions among six radiologists. AJR Am J Roentgenol 2 $021 ; 1-11$.

3. Oshio K, Okuda S, Shinmoto H. Removing ambiguity caused by T2 Shine-t hrough using weighted diffusion subtraction (WDS). Magn Reson Med Sci $2016 ; 15(1): 146-148$.

4. Rosenkrantz AB, Meng X, Ream JM, et al. Likert score 3 prostate lesio ns: Association between whole-lesion ADC metrics and pathologic findi ngs at MRI/ultrasound fusion targeted biopsy. J Magn Reson Imaging201 $6 ; 43(2): 325-332$. 